Asia Proceedings of Social Sciences

(APSS)

www.readersinsight.net/APSS

\title{
Going Public Decision of Initial Public Offerings (IPO) in Hot Issue Market: Case of Pakistan Stock Exchange
}

\author{
Shehzad Khan* \\ Institute of Business Studies and Leadership (IBL), Abdul Wali Khan University Mardan, \\ Pakistan
}

\section{Kiran Alim}

Univesity College for Women (UCW), Abdul Wali Khan University Mardan,

Pakistan

\section{Suresh Ramakrishnan}

Azman Hashim International Business School, Department of Accounting \& Finance Faculty of Management, Universiti Teknologi Malaysia Johor Bahru.

Malaysia

*Corrosponding author's Email: shehzadkhantopi@gmail.com 


\section{Research Highlights}

The study explored the direct impact of industry effect on the going public decision during hor isuue market in Pakistan. The study found that the industry condition such as; munficance, dynamism and HHI along with firm-level, and country level factors played an important role in determining firm's going public decision during hot issue market.The findings of the study strongly supported the conventional wisdom of signaling, changing risk composition, information spill-over, and capital demand hypothesis.

\section{Research Objectives}

The aim of the study is to examine the significant factors that influence the going public decision of IPOs in Pakistan during hot issue market. The study fisrtly identified the hot and cold issue periods in Pakistan by using volume based method. The study secondly examined the imapct of firm level, industry level and country level factors on going public decision in Pakistan. The study thirdly explored whether and going public theories are pertient to Pakistan.

\section{Methodology}

The analysis of all non-financial firms listed on the Pakistan Stock Exchange (PSX) was conducted from the period of 2000 to 2015 . This study utilized the volume and initial returnsbased method to identify the hot and cold issue markets. The logit regression model is used to examine the significant determinants of going public decision during hot issue market. 


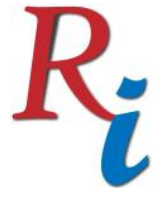

\section{Asia Proceedings of Social Sciences \\ (APSS) \\ www.readersinsight.net/APSS}

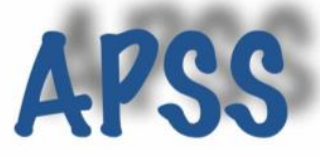

\section{Findings}

The result indicated that the largest number of IPOs per year were issued around the year 2003-2005, 2007 and 2014-2015 trailed by the inflated underpricing, known as hot issue market. Nevertheless, the periods between 2000-2002, 2006, 2008-2013 are declared as cold issue market, where less number of IPOs and underprcing is observed. The result further shows that the industry condition along with firm-level, and country level factors played an important role in determining firm's going public decision during hot issue market. The findings of this study strongly supported the conventional wisdom of signaling, changing risk composition, information spill-over, and capital demand hypothesis. The findings of the study is consistent with previous literature (Alim et al., 2017; Shehzad Khan, 2017; Khan et al., 2016; Khan et al., 2014; Benveniste et al., 2002).

\section{References}

Alim, Kiran, Ramakrishnan, Suresh, Khan, Shehzad, \& Malik, Faizan, Muhammad. (2017). Initial Public Offerings (IPO) Performance during Hot and Cold Issue Market in Pakistan. International Journal of Applied Business and Economic

Benveniste, Lawrence M, Busaba, Walid Y, \& Wilhelm, William J. (2002). Information externalities and the role of underwriters in primary equity markets. Journal of Financial Intermediation, 11(1), 61-86.

Khan, Shehzad, Ahmad Anuar, Melati, Muhammad, Malik, \& Ramakrishnan, Suresh. (2016). Short-Run Underpricing of Initial Public Offerings (IPOs): A Conceptual Review. International Business Management, 10(6), 842-848.

Khan, Shehzad, Anuar, Melati Ahmad, \& Malik, Muhamamd Faizan. (2014). Review of short term and long term performance of initial public offering. Sains Humanika, 2(3).

Shehzad Khan, Suresh Ramakrishnan, Muhammad Faizan Malik. (2017). Long-run Underperformance of Initial Public Offerings (IPO) in Pakistan. Advanced Science Letters, Accepted for Publication. 